\title{
Канунников Р.И. \\ Роль мотивации в процессе формирования правосознания у сотрудников органов внутренних дел
}

Уральский юридический институт МВД России (Россия, Екатеринбург)

doi: $10.18411 / \mathrm{lj}-06-2021-210$

\section{Аннотация}

В научной статье дается анализ роли мотивации в процессе формирования правосознания у сотрудников органов внутренних дел. В работе исследуются возможности формирования положительной мотивации, способствующей преодолению деформаций правосознания у сотрудников органов внутренних дел.

Ключевые слова: мотивация, правосознание, деформации, ценности.

\section{Abstract}

The scientific article analyzes the role of motivation in the process of forming legal awareness among employees of internal affairs bodies. The paper explores the possibilities of forming a positive motivation that helps to overcome the deformations of legal consciousness among employees of internal affairs bodies.

Keywords: motivation, sense of justice, deformations, values.

Процесс формирования правосознания в российском обществе имеет одно из ключевых значений. Построение системы духовно-нравственных ценностей сопряжено с изменениями, происходящими в обществе. Всевозрастающая динамика и многообразие социокультурных процессов как отличительная черта современности имеет следствием многочисленные деформации правосознания. В связи с этим особо остро стоит вопрос понимание влияние мотивационных процессов на формирование правосознания.

В связи с этим, огромное значение приобретает процесс формирования правосознания в образовательных организациях МВД России. Становление правосознания в таких образовательных учреждениях зависит от целенаправленной политики в сфере формирования гражданско- патриотического воспитания, способствующего в свою очередь формированию правосознания. Нередко в этот процесс вовлекаются представители духовенства, пропагандирующие нравственные ценности у будущих сотрудников территориальных подразделений МВД России.

Само понимание понятия профессионального правосознания у сотрудников правоохранительных органов трактуется не однозначно.

Так, в исследованиях Н.Л.Гранат, правосознание полицейских - это знания о правовой деятельности, включающие в себя не только отдельные аспекты служебной деятельности, но и саму форму проявления правосознания.

Н.Я. Соколов, придерживается иного мнения считая, что правосознание сотрудников органов внутренних дел это система взглядов и убеждений направленных на оценку действий, чувств, взаимоотношений относящихся к служебной деятельности.

Особенности правосознания полицейских, как правило, формируются в ходе выполнения профессиональной деятельности. $\mathrm{K}$ ним чаще всего относят профессиональные знания, умения и навыки, правовые убеждения, эмоциональное отношение к нормам права, правовую культуру.

Вместе с тем следует отметить, что правосознание сотрудников полиции поляризационно. Это обусловлено прежде всего такими показателями как уровень образования, форма обучения, гендерные различия, ценностные ориентации, мотивация. 
Мотивация в процессе формирования правосознания у сотрудников правоохранительных органов приобретает особое значение. Мотивация к выполнению служебной деятельности является процессом выработки личностью сотрудника своей собственной позиции по отношению к целям деятельности, к возможным путям их достижения.

Правосознание сотрудника правоохранительных органов в первую очередь должно быть ориентировано на понимание сути служебной деятельности. Влияние норм права на служебную деятельность приводит к изменению в правосознании, приводящие затем к смене системы ценностей.

Необходимо понимать, что особенности правосознания не являются раз и навсегда сформированными. Очень часто под влиянием различных средовых факторов происходят незаметные для окружающих изменения в правосознании. Поэтому, руководству важно отслеживать смену ценностных ориентаций и мотивации сотрудника полиции. Вместе с тем, необходимо использовать мотивационное подкрепление.

Такого рода мотивационное подкрепление может быть различным от материального до морального поощрения или наказания.

Профессиональная деятельность сотрудников правоохранительных органов является специфическим видом профессиональной деятельности, которая определяет требования к личности и предполагает наличие сформированности определенных характеристик. Одной из таких характеристик является устойчивая мотивация к службе в правоохранительных органах, предполагающая наличие и доминирование у сотрудников профессиональных мотивов, не только в период службы, но и в период обучения.

В образовательной системе МВД России регистрируется все большое количество добровольных отчислений курсантов. Исходя из этого, требуется постоянный мониторинг мотивационного компонента составляющего их учебную и служебную деятельность с целью сокращения подобных случаев.

Сформированность положительной мотивации к учебе побуждает обучающихся в образовательных организациях МВД России совершенствовать свои профессиональные качества.

Функциональные возможности сотрудника полиции зависит в первую очередь от наличия у него мотивов к выполнению профессиональной деятельности. Вместе с тем лишь совокупность мотивов и трудолюбия позволяет наиболее эффективно реализовать свои возможности в служебной деятельности.

При этом «главным» мотивом профессиональной самореализации сотрудника полиции должно стать стремление к защите законных интересов, прав и свобод граждан от преступных посягательств, а не стремление к продвижению по служебной деятельности.

Материальное подкрепление в виде премий и продвижения по службе чаще всего на первый взгляд является особенно эффективным. Но в то же время необходимо понимать и степень его воздействия на правосознание сотрудника. В некоторых случаях такое подкрепление может способствовать укоренению представлений о своей непогрешимости, восприятии такого подкрепления как нечто должного. В этом случае мотивационное подкрепление выступает в виде негативного фактора, приводящего в последствии к различного рода деформациям правосознания.

Знания, ценности, идеалы сформированные у сотрудника органов внутренних дел получают свою жизненность лишь тогда, когда они, будучи основой мировоззрения, обретают качество убеждения. Убежденность является составляющим элементом мировоззрения и потому образует его стержень, раскрывает устойчивую и психологическую установку в правильности принятого решения и последующих за ним действий. 
Главное в убеждении - это уверенность в правоте своих взглядов. Руководствуясь убеждениями и ради их выполнения, сотрудник полиции подчиняет свои чувства, совесть, волю и поступки защите прав граждан. Сформированное мировоззрение позволяет определить жизненную позицию сотрудника полиции к выполняемой им профессиональной деятельности.

Одним из способов мотивационного подкрепления выполнения служебной деятельности может стать процесс вовлечения поднятия морально- нравственных норм с помощью представителей духовенства. Религиозные деятели на сегодняшний день активно вовлекаются в образовательный процесс системы МВД формируя положительное отношение к профессии. В связи с этим мы считаем, что необходимо такую работу продолжить и в территориальных органах внутренних дел.

Формирование положительного имиджа сотрудника полиции также является своего рода мотивационным подкреплением, направленным как на выбор профессии, так и на стремление качественно выполнять служебную деятельность. Негативное отношение к полиции существующие в общественном мнении необходимо менять. Большая роль в этом процессе принадлежит конечно же СМИ. Но каким бы ни был целенаправленно конструируемый имидж (образ) ОВД, он обязательно сопоставляется с непосредственными впечатлениями и корректируется, если медиаобраз противоречит жизненным реалиям. Именно от многолетнего взаимодействия с конкретными представителями полиции, юстиции и внутренней службы, в конечном счете, зависит результат восприятия органов внутренних дел - их репутация. Однако надо учитывать, что личный опыт накапливается медленно и может быть противоречивым (например, в течение одного и того же дня общение с участковым оставило хорошее впечатление, а общение с «гаишником» - плохое). Поэтому медиаобраз хотя и корректируется, но продолжает влиять даже на людей с большим жизненным опытом.

СМИ создают модели сотрудников различных подразделений ОВД (полицейских патрульно-постовой службы, следователей, участковых уполномоченных, работников уголовного розыска, руководителей полиции) в различных медийных продуктах - в новостных сообщениях, аналитических комментариях, телесериалах и фильма.

Мотивационное подкрепление у сотрудников органов внутренних дел должно способствовать стремлению к саморазвитию в профессиональной деятельности, достижению успеха, возникновению самопознания и самоанализа своих действий, к реализации своих качеств в защите и соблюдении прав граждан.

Мотивация профессиональной деятельности организует и регулирует поведение в процессе выполнения служебной деятельности, повышает профессиональную активность, влияет на формирование цели и на выбор путей оптимального ее достижения. Наличие высокого уровня положительных мотивов служебной и познавательной деятельности обеспечивают предпосылки для формирования правосознания.

Таким образом роль мотивационного подкрепления в формировании является важной. Выбор формы такого подкрепления зависит от руководства, ближайшего окружения и самого сотрудника.

$$
* * *
$$

1. Безруков А.В. Правосознание как фактор мотивации правомерного поведения. - Мурманск: МГТУ, 2009. - 195 с.

2. Балаклеец И.И. Правовая культура современной России в условиях становления гражданского общества и правового государства//Вестник Калининградского юридического института МВД России. - 2009. - № 2. - С. 134-139.

3. Семчук И. Психологические аспекты формирования профессиональных качеств сотрудника ОВД // Профессионал. 2013. - № 6. С. 33-38.

4. Татару Б. А. Факторы, влияющие на формирование профессионального правосознания сотрудников ОВД // Вестник СевКавГТИ. 2017.- № 3 (30). С. 93- 117. 